\title{
The Influence of Parenting Patterns and Family Socio-Economic Status with Language Ability on Children's Social Development
}

\author{
Elly Sari *, Ali Rachman, Metroyadi \\ Master Program of Early Childhood Teacher Education, Universitas Lambung Mangkurat, Banjarmasin \\ 70123, Indonesia
}

\section{Article history:}

Submission Septermber 2020

Revised December 2020

Accepted December 2020

*Corresponding author: E-mail:

ellyadunk@gmail.com

\begin{abstract}
Education is a crucial thing to give from an early age, providing the right education at an early age is the right thing to do to produce a generation of champions who can win the competition in the global world. The study aims to identify the effect of parenting style, family socioeconomic status, language skills, and children's social development in kindergarten and Pelaihari village Tanah Laut District. The study uses a quantitative approach with explanatory methods, including cause and effect. It had a population of 330 , and a total of 155 people were selected using a proportional sample technique. The research instruments were questionnaires. To analyze the collected data the re-searcher used regression and path analysis. The results show that: first, Parenting patterns of Language Skills with 0,006 . second, Family Socio-Economic Status on Language Skills by 0,035. third, parenting patterns for children's social development by 0,025 . fourth, the socio-economic status of the family on the social development of children by 0,017 . fifth, Language Ability on Child Social Development on children's social development by 0,027 . sixth, there is no indirect influence on parenting through language skills by $0,188 \& 0,040$. Lastly, there is no indirect influence on the socio-economic status of the family through language skills on children's social development by $0,199 \& 0,038$. For this reason, parents need to understand how to educate children in developing social development and advance self-understanding in everyday life.
\end{abstract}

Keywords:Parenting, family socioeconomic status, language skill, child's social development

\section{Introduction}

Children are vital assets in developing human resources (HR) for the future of a nation. To be able to realize the quality and competitive HR, early childhood education is the key (Pramling Samuelsson, 2011). Giving special attention to education in terms of early childhood education is the right strategy to do to produce a generation of champions who can increase the nation's competitiveness (Hägglund \& Samuelsson, 2009). Thus, it is important to understand and get curious about the children's development along with their education. The development that occurs in early childhood includes all aspects of life they live, both physical and non-physical (Malina, 2004). Children's life in tracing their development is their ability to interact with the environment, namely in the process of integration and interaction with the environment. Through this process of integration and interaction, intellectual and emotional factors play a very important role and this process is a socialization process that places children as human beings who are actively involved in the socialization process. Although it may not be explicitly revealed in the children's development, socialization is the phase that must be through and it can be achieved by mastering the language spoken by their environment. 
Language skills are synonymous with communication between parents and children (King \& Fogle, 2006). In this concept, parents and children need to build a bond together through language as they are the very first environment being encountered by the children. Hence, parental communication is one of the tools for language development that needs to be developed in the world of children (Topping et al., 2013). The continuation of learning language which is helped by parents will lead to children's good speaking and great socialization ability. It is because language skills will continue to be developed so that children can interact with the community. By keep learning to be able to speak and communicate, children can convey what they think, can interact with the community, express expressions, and express feelings to others. For, children's language skills begin through the environment around the child's life. Therefore, the language known to children is the mother tongue (Baiti et al., 2019). This mother-tongue usually is being called the mother language as well, which is the language their parents use in their daily speaking instrument. Children will hear this language every day and it is the easiest way to teach them to use them before knowing other languages.

As children keep growing, language skills will continue to be developed so that children can interact with the community. The benefit of this is, along with the time, children can convey what they think, can interact with the community, express expressions, and express feelings to others. As it has been elaborated before, children's language skills begin through the environment around the child's life. Thus, close relationships between parents and children are very important to develop in the family (Salisch, 2001; Dalle \& Mutalib, 2010). The closeness of the relationship can be seen from the frequency of meetings between parents and children at a time and occasion. Children and parents can have time during daily activities or making occasions through planned vacation or dining out once a week or month. During this time and occasion, they may have more time to speak and get real closeness. Without realizing it, parents are developing their children speaking and communicating ability.

Henceforth, the problem of time and opportunity is a determining factor for the success or failure of a meeting, actually meeting family members to sit together at a time and opportunity is very important as a symbol of family intimacy (Spagnola \& Fiese, 2007). Communication is a basic need for every child because it is a social creature who must live side by side with one another (Cologon \& Mevawalla, 2017). Children always adjust to the social environment (Kawabata et al., 2010). One form of communication is the ability to speak (Chen \& Starosta, 1996). The ability to communicate is the ability to convey thoughts, ideas, and feelings felt by children (Rizzuto, 2002). Children's speaking ability can be seen from the number of children who say complex words and sentences that he utters in a certain unit of time. Every child develops at a different rate even though they are the same age (David \& Wei, 2008). The biggest influence on children's language development is how much they are invited to speak.

Communication is a basic human need, especially for every child because it is part of a social being that must coexist with each other (Suriansyah, 2014). Children always adapt to the social environment. One form of communication is speaking ability. It is important to get achieved because without this ability children will not be able to become completely part of society since communication is needed most to express feeling and argue thought. Without them, children can grow up restricted with no chance to speak up.

Additionally, communication between parents and their young ones enhances social abilities. Communication is the process of exchanging information from one person to another through media with symbols, signs, or behavior that are equally understood (Mish, 2009). It is the primary tool that people can use to express their ideas and values (Suleman \& Zairi, 2001), therefore, in everyday life, people usually spend more than $50 \%$ of their conscious time communicating (Romas \& Sharma, 2017). It is a term that comes from the Latin word communis, which means "the same" which refers to 
"same meaning" (Sugiharto \& Ramadhana, 2018).

How to communicate with each person might differ significantly, for instance, between children and parents, which is categorized based on interpersonal communication. It is face-to-face communication, allowing each individual to directly catch other people's reactions, both verbally and non-verbally (Wardani et al., 2019). This type of communication should be done between parents and children as the very first people should be understood very well by the children is their parents. Henceforward, the society will be easy for them to get communicated after mastering the communication with their parents.

The family is obliged to provide all needs related to education. Parental care about the process of the education of the son of his daughter in school was formed from the accumulation of experiences, events, and events internally and externally. Factors internally include the background of life parents, relationships or interactions between parents with the son of his daughter, the level of education of the person old, economic level or income of parents (Aslamiah \& Rizalie, 2015). The assumption that families who have the high socio-economic status of parents will not have much difficulty in meeting the needs of children, while families that have low socioeconomic status will experience difficulties in meeting the needs their children in this case the provision of the stimulus (Smits \& Hoşgör, 2006). The work of parents who also includes indicators in socioeconomic status relates to children's speaking skills, parents whose workforces to work outside the home and lack of understanding of children's language development will have difficulty in providing stimuli to stimulate children's language development and rarely interact with children (Zain et al., 2018).

The factors that influence children's communication are health, intelligence, socioeconomic conditions, gender, desire to communicate, encouragement, number in the family, birth order, child training methods, multiple births, peer relationships, and personality (Kemendikbud, 2013). Several studies on the relationship between language development and social status of several families show that children from poor families experience delays in developing their language compared to children from better families. Theoretically, the introduction of the initial language is needed to acquire good language skills, as stated by (Yusuf, 2000) that language development is influenced by health, intelligence, socioeconomic status, gender, and family relationships.

Also, the socioeconomic status of the family is a significant factor in the development of language in the family. According to (Sunarto, 2004) a family with good socioeconomic status will be able to provide a good situation for children's language development. This is of course from family background and provides different life necessities such as fashion, play facilities, communication with children, and the views of parents about children, differences in the cultivation of moral values and habits at home. Early childhood education is the initial foundation in shaping children's character (Salasiah et al., 2018). The socioeconomic status in the family describes a person's condition in economic terms with a description of the level of education, income, and employment. Each community wants a better socioeconomic status. The socioeconomic status of the family also affects communication between individuals in the family (Ankrum, 2016). Intense communication is very important for interpersonal relationships, especially in families (Ritchie \& Fitzpatrick, 1990).

Socio-economic status is a level that is owned by someone who is based on the ability to meet the daily needs of income or income so that it has a role in one's social status in the structure of society. Certain income or occupations can also determine a person's status in society (Ganzeboom et al., 1992). Children from higher socioeconomic levels have an easy tendency to communicate because children are often encouraged to express their feelings. However, not all of the children in the socioeconomic level are high, the level of development of the language is longer and more complex, and on the contrary children who have a low social level far exceed many have longer and more complex sentences. The above explains above that it is possible for the family's eco- 
nomic status to be a benchmark for the development of children's language but is also tied to parenting applied by parents at home (Suriansyah \& Aslamiah, 2015).

In social development, there is a process of interaction between children and the social environment, which in turn will affect and be influenced by one another. The social environment in question includes parents, school, peers, and adults. An environment that is good, peaceful, peaceful, safe, full of acceptance and understanding, and can protect its members in an environment that will facilitate the process of social development, on the other hand, if the individual lives in an environment that is not peaceful, unsafe and unsafe, then the individual will experience a disruption in the process of social development. For that children need to be taught to use language or speak in a kind and polite words to facilitate their social life (Scarcella \& Brunak, 1981).

Language is a communication tool for humans to convey thoughts and feelings through the learning process. Mastery of language is carried out in stages through the introduction of objects in the environment to form a vocabulary. Someone speaks actively, that is, someone can express ideas and thoughts to others, and can understand and understand other people's language both orally and in writing. According to Purwanti et al. (2018) the development of children's language from birth to six (06) years is a golden period and very important. Children's language skills are obtained from family, neighbors, school, and playmates, also, language skills are included in the character values developed through the curriculum in schools. What teachers teach in school results will be accepted by students and sent to parents (Suhaimi \& Rinawati, 2018).

A language is a tool used by children to live together with other people (Wiyani N. A., 2015). Children's speaking ability is seen from the amount spoken by the child in the form of complex words and sentences that he utters at a certain time. Every child develops at a different rate even though they are the same age. The biggest influence on children's language development is how many times they are allowed to speak or reveal something. Parents' responsibility in the children's education is not limited to providing proper education for children, but also educating children at home (Bakar, Mamat, \& Ibrahim, 2017). Providing knowledge and providing an understanding of some values which are rarely the focus of education in schools is the obligation of parents to their children. The basic unit of children's education is a family (Kainuwa \& Yusuf, 2013), where they learn about self-confidence before enrolling in informal learning institutions. This means early education starts within the family before the child joins formal education. The development of the required children's character is indicated by the level of family influence (Maimunah et al., 2018).

Considering those problems above, this study identified the Influence of Parenting Patterns and Family Socio-Economic Status with Language Ability on Children's Social Development. Specifically, it focuses on the influence of the following:

1. Overview of parenting styles, family socioeconomic status, language skills, and children's social development

2. The influence of parenting affects language skills

3. The influence of family socioeconomic status affects language skills

4. The influence of parenting has a direct effect on children's social development

5. The socio-economic influence of the family directly affects the social development of children

6. The influence of language skills has a direct effect on children's social development

7. The influence of parenting through language skills has an indirect effect on children's social development

\section{Material and Methods}

This research uses a quantitative descriptive comparative. This research was conducted by using tests as data collectors on samples from a particular population and further described using statistical models to confirm existing theories. This assertion is in line with Arikunto (2015), who stated that correlational 
research determines how strong the relationship is between variables. A high correlation means that there is a strong relationship between the variables studied, while a weak correlation means that the variables studied have almost no relationship (Franzese \& Iuliano, 2019).

This study is intended to determine the relationship between the four variables, including parenting $\left(\mathrm{X}_{1}\right)$, family socioeconomic status (X2) as the independent variable and language skill (Z) as the correlator variable, and the child's social development (Y). The population is a subject or object that has certain qualities and characteristics that the researcher determines to study and then draw conclusions (Sugiyono, 2017).

The population of the study consists of the parents of children in Pelaihari Kindergarten. The accessible population included 330 parents. Importantly, this study used cluster sampling to determine each school sample, which consists of individual groups or clusters. A total of 155 parents of children attending these ten schools were used as samples. The research institution uses questionnaires on a Likert scale, while path analysis was used to analyze data.

\section{Results and Discussion \\ The significance effect of parenting patterns on language skills}

This study found that there was a significant effect of parenting on language skills, between variables known to be influential due to the significance value $(0.006<0.05)$, so it can be concluded in this study between variables directly there is a significant influence between parenting (X1) on children's language skills (Z).

The calculation result of the path analysis coefficient of information beta of 0.223 , which means the magnitude of the correlation between the parenting style variable and children's language skills is 0.252 and is considered influential because it is included in the criteria $0.20-0.399$ which means low. As for the significance between the parenting style variables and children's language skills, there is sig 0.006 .

Parenting style is an implementation of the attitudes and behavior of parents towards their children, which will create an atmosphere of the parent-child relationship. Because the attitudes and behaviors of parents will shape children's development (Zecevic et al., 2010). Parents as leaders and mentors of children in the family are indeed required to be wise towards emotional turmoil or typical attitudes of children. Parents are the most responsible for their children's lives. Parenting style is very important for children to help their children's interest in learning. If children are given attention by their parents, they will have a high interest in learning. The greater the attention of parents to their children, the greater their interest in learning. Parenting is not just the parents, but can also involve teachers guiding children in learning at school.

\section{The effect of family's socio-economic status on language skills}

Based on the results of the calculation of the path analysis coefficient of information beta of 0.170 , which means the magnitude of the correlation between the direct variables of family socioeconomic status and children's language skills is 0.170 and is considered influential because it is included in the criteria 0.20 - 0.399 which means low. As for the significance between the sig. Sig. Economic status and parental interactions there is 0.035 . Between variables are known to be influential due to the significance value $(0.035<0.05)$, so it can be concluded in this study that between variables directly there is a significant influence between the direct socioeconomic status of the family (X2) on children's language skills (Z).

The state of the socioeconomic status of the family has an important role in the education and development of children, this is in line with the research conducted that the socioeconomic status affects the development of children, one of which is the children's social skills. A sufficient economy in the form of material ownership faced by children in their families will have an impact on the children. This condition is very good for the child to get the opportunity to develop a wider variety of skills. In addition to material ownership, parental education also plays a role in children's education, because the high/low level of education that parents have or achieve is likely to influence their children. 


\section{The influence of language skills on children's social development}

Based on the results of the calculation of the path analysis coefficient of information beta of 0.188 , which means the magnitude of the correlation between the variables of parenting and social development of children is 0.188 and is considered influential because it is included in the criteria $0.00-0.199$ which means very low. As for the significance between the variables of parenting and social development of children, there is sig 0.025. Between variables known to be influential due to the significance value $(0.025<0.05)$, so it can be concluded in this study between variables directly there is a significant influence between parenting (X1) on children's social development $(\gamma)$.

Language skills are an important requirement in a child's life, namely the need to be part of a social group. Language learning is directed at improving children's ability to communicate in the good and correct language, both verbally and in writing, as well as fostering an appreciation of human literary works. In essence, language learning is learning communication. Therefore, language learning is directed at improving the ability of learners to communicate, both oral and written (Dir PAUD, 2002). Thus, a supportive environment greatly influences children's language development for socializing.

\section{The effect of family socio-economic status on children's social development}

Based on the results of the calculation of the path analysis coefficient of information beta of 0.199 , which means that the magnitude of the correlation between the socio-economic variables of the family and the social development of children is 0.199 and is considered influential because it is included in the criteria $0.20-0.399$ which means low. As for the significance between family socio-economic variables and children's social development, there is sig 0.017 . Between variables known to be influential due to the significance value $(0.017<0.05)$, so it can be concluded in this study between variables directly there is a significant influence between family socioeconomic (X2) on children's social development $(\gamma)$.
The state of the socioeconomic status of the family has an important role in the education and development of children, this is in line with the research conducted that the socioeconomic status affects the development of children, one of which is the children's social skills. A sufficient economy in the form of material ownership faced by children in their families will have an impact on the children. This condition is very good for the child to get the opportunity to develop a wider variety of skills. In addition to material ownership, parental education also plays a role in children's education, because the high/low level of education that parents have or attain is likely to influence their children (Martin, 2013).

The economic role of parents in general can be said to have a positive influence on improving children's learning. This is because the teaching and learning process of students requires tools or a set of teaching or learning, where this tool is to make it easier for students to get information, management of learning materials obtained from the school.

\section{The effect of family socio-economic status on children's social development}

Based on the results of the calculation of the path analysis coefficient of information beta of 0.199 , which means that the magnitude of the correlation between the socio-economic variables of the family and the social development of children is 0.199 and is considered influential because it is included in the criteria $0.20-0.399$ which means low. As for the significance between family socio-economic variables and children's social development, there is sig 0.017 . Between variables known to be influential due to the significance value $(0.017<0.05)$, so it can be concluded in this study between variables directly there is a significant influence between family socioeconomic (X2) on children's social development $(\gamma)$.

The state of the socioeconomic status of the family has an important role in the education and development of children, this is in line with the research conducted that the socioeconomic status affects the development of children, one of which is the children's social skills. A suffi- 
cient economy in the form of material ownership faced by children in their families will have an impact on the children. This condition is very good for the child to get the opportunity to develop a wider variety of skills. In addition to material ownership, parental education also plays a role in children's education, because the high/low level of education that parents have or attain is likely to influence their children (Martin, 2013).

The economic role of parents in general can be said to have a positive influence on improving children's learning. This is because the teaching and learning process of students requires tools or a set of teaching or learning, where this tool is to make it easier for students to get information, management of learning materials obtained from the school.

\section{The direct influence of language skills on children's social development}

Based on the results of the calculation of the path analysis coefficient information beta of 0.183 , which means that the magnitude of the correlation between the variable language skills and children's social development is 0.183 and is considered influential because it is included in the criteria $0.00-0.199$ which means very low. Meanwhile, the significance of the variable language skills and children's social development is sig 0.027 . Between variables are known to be influential due to the significance value $(0.027<0.05)$, so it can be concluded in this study between variables directly there is a significant influence between language skills $(Z)$ on children's social development $(\gamma)$.

The indirect influence between parenting patterns through language skills on children's social development

Based on the calculation results, it is known that the direct effect of parenting (X1) on children's social development $(\gamma)$ is 0.188 . While the indirect effect of parenting (X1) through language skills (Z) on children's social development $(\gamma)$ is the multiplication of parenting beta values (X1), language skills (Z), and language skills beta values $(\mathrm{Z})$ on development. social children $(\gamma)$, namely $0.223 \times 0.183=0.040$. Then the total influence given by parenting (X1) on children's social development $(\gamma)$ is the direct effect plus the indirect effect $0.188+$ $0.040=0.228$. Based on the results of the above calculations, it is known that the value of the direct effect is 0.188 and the indirect effect is 0.040 , which means that the value of the direct effect is greater than the indirect effect. This result shows that indirectly parenting (X1) through language skills (Z) does not have a significant influence on children's social development $(\gamma)$.

\section{The indirect influence between the socioeco- nomic status of the family through language skills on children's social development}

Based on the results of the calculation, it is known that the direct effect given by the socioeconomic status of the family (X2) on the social development of children $(\gamma)$ is 0.199 . While the indirect effect of family socioeconomic status (X2) through language skills (Z) on children's social development $(\gamma)$ is the multiplication of the beta value of family socioeconomic status (X2), on language skills ( $\mathrm{Z}$ ) and the beta value of language skills (Z).) to the child's social development $(\gamma)$, namely $0.170 \times 0.183=0.031$. Then the total effect is given by family socioeconomic status (X2) on children's social development $(\gamma)$ is the direct effect plus the indirect effect $0.199+0.031=0.23$ Based on the results of the above calculation, it is known that the value of the direct effect is 0.199 and the indirect effect is 0.031 , which means that the value of the direct effect is greater than the indirect effect. This result shows that indirectly the socioeconomic status of the family (X2) through language skills (Z) does not have a significant effect on children's social development $(\gamma)$, see Table 1.

Table 1. Structural model coefficient I

\section{Coefficients $^{\mathrm{a}}$}

\begin{tabular}{|c|c|c|c|c|}
\hline Model & $\begin{array}{c}\text { Unstandardized Coeffi- } \\
\text { cients } \\
\end{array}$ & $\begin{array}{c}\text { Standardized } \\
\text { Coefficients }\end{array}$ & $\mathrm{t}$ & Sig. \\
\hline
\end{tabular}


E Sari, 2020 / The influence of parenting patterns and family socio-economic status with language ability

\begin{tabular}{rlrrrrr}
\hline & & & & & & \\
\hline 1 & B & Std. Error & Beta & & \\
& (Constant) & 21.702 & 3.402 & & 6.379 & .000 \\
& Parenting & .222 & .080 & .223 & 2.778 & .006 \\
& $\begin{array}{l}\text { Family Socio-Eco- } \\
\text { nomic Status }\end{array}$ & .100 & .047 & .170 & 2.123 & .035 \\
\hline
\end{tabular}

a. Dependent Variable: language skills

Table 2. The structural summary model I

\begin{tabular}{llrrr}
\hline Model & \multicolumn{2}{c}{} & & \multicolumn{2}{c}{$\begin{array}{c}\text { Std. Error of the Esti- } \\
\text { mate }\end{array}$} \\
\hline 1 & & R Square & Adjusted R Square & 3.83860 \\
\hline
\end{tabular}

a. Predictors: (Constant), Family Socio-Economic Status, Parenting

Table 3. Structural model coefficient II

\section{Coefficients}

\begin{tabular}{|c|c|c|c|c|c|c|}
\hline \multirow{2}{*}{\multicolumn{2}{|c|}{ Model }} & \multicolumn{2}{|c|}{$\begin{array}{l}\text { Unstandardized Coeffi- } \\
\text { cients }\end{array}$} & \multirow{2}{*}{$\begin{array}{c}\text { Standardized } \\
\text { Coefficients } \\
\text { Beta }\end{array}$} & \multirow[b]{2}{*}{$\mathrm{t}$} & \multirow[b]{2}{*}{ Sig. } \\
\hline & & B & Std. Error & & & \\
\hline \multirow[t]{4}{*}{1} & (Constant) & 71.552 & 12.815 & & 5.583 & .000 \\
\hline & Parenting & -.622 & .274 & -.188 & -2.269 & .025 \\
\hline & $\begin{array}{l}\text { Family Socio-Economic Sta- } \\
\text { tus }\end{array}$ & .388 & .161 & .199 & 2.416 & .017 \\
\hline & Language Skills & .607 & .271 & .183 & 2.237 & .027 \\
\hline
\end{tabular}

a. Dependent Variable: Perkembangan Sosial Anak

Table 4. Structural summary model II

\begin{tabular}{|c|c|c|c|c|}
\hline Model & $\mathrm{R}$ & R Square & Adjusted R Square & $\begin{array}{c}\text { Std. Error of the Est } \\
\text { mate }\end{array}$ \\
\hline 1 & $.293^{\mathrm{a}}$ & .086 & .068 & 12.841 \\
\hline
\end{tabular}

a. Predictors: (Constant), Language Skills, Family Socio-Economic Status, Parenting 
The results showed that family communication, especially parents, had a significant effect on children's social development. Children's personalities and must be trained in children as early as possible optimally to avoid hindering their development (Damayanti, 2020). Appropriate parenting help children understand their lives and the problems faced, especially in developing social abilities. The children's social abilities can be seen through their ability to choose friends, independent learning in class without parents, and sharing food with their friends (Wiyani, 2014). A child with good social ability could communicate easier with others to socialize, cooperate, and interact effectively with the environment (Lestiawati, 2013). The warmth of a parent in the family affects the child's subsequent relationship in adulthood. Parental interactions influence children's social relations either directly or indirectly, besides this interaction also affects children's social contacts with social partners outside the family.

The attention of parents to children from an early age is crucial to the development of the soul and character (Suriansyah \& Mahriati, 2016) since this age is a crucial period in shaping the child's personality, which will affect the development of his personality in the future (Vasilyeva \& Shcherbakov, 2016).

The communication between parents and children helps in dealing with problems (Zhang, 2007). Communication in a family should be open both for the bad and good situation and ready to deal with problems patiently, honestly, and openly (Wahidah, 2011). Self-openness has an important role in building closeness and confidence in a family (Ardhaneswari, 2018). Generally, most problems that arise in children are attributed to a lack of communication by parents.

Effective interpersonal communication is characterized by openness, empathy, supportive behavior, positive behavior, and equality among communication actors (Rakhmat, 1998), mostly observed in a democratic parenting family (Amir \& Trianasari, 2013). It could highly influence the individual personality (Streeck, 1994). The intensity of communication in the family eventually influences the fam- ily behavior, closeness among the family members, or on the contrary, brings problems (Djuwitaningsih, 2018). The more often parents interact with their children, the better the child's communication skills; besides that this ability will also shape the child's ability to be able to interact better with the people around them (Runcan et al., 2012).

\section{Conclusion and Recommendation}

Based on the results of the study, it can be concluded that there is an influence of.

1. There is a direct effect of parenting on language skills.

2. There is a direct effect of family socioeconomic status on language skills.

3. There is a direct effect of parenting on children's social development.

4. There is a direct effect of Family SocioEconomic Status on Children's Social Development.

5. There is a direct effect of Language Ability on Children's Social Development.

6. There is no indirect effect of parenting through language skills on children's social development.

7. There is no indirect effect of family socioeconomic status through language skills on children's social development

Based on the results of the study, the following recommendations are offered:

1. Schools should pay more attention to children, Suggestions for improving social development in children by looking at factors that enhance social development itself, focused on simple activities that involve cooperation with friends.

2. Parents should pay more attention to observe children's social behavior at home and not to pressure them.

3. The input material in understanding the influence of parental roles and parenting through communication on social independence should be examined more deeply in future studies.

Since this study is limited to parents' role in the children's personality other studies that explore parents' role for other things related to children's education need to be conducted. Those studies will help the educational institution to give a better education. 


\section{Acknowledgment}

This work was supported by Research Center for Universitas Lambung Mangkurat, Banjarmasin.

\section{References}

Amir, A. S., \& Trianasari. (2013). Interpersonal communication patterns in parenting: The case of parents with different religion. Jurnal Komunikasi Kareba, 2(1), 12-29.

Ankrum, R. J. (2016). Socioeconomic Status and Its Effect on Teacher/Parental Communication in Schools. Journal of Education and Learning, 5(1), 167-175. doi:10.5539/jel.v5n1p167

Ardhaneswari, G. Y. (2018). Communication between parents and children (A descriptive qualitative study on openness of adolescent to a single mother related to sexual behavior in Karangtengah Village, Ngawi Regency). Surakarta: Faculty of Communication and Information, University of Muhammadiyah Surakarta.

Arikunto, S. (2015). The basis of educational evaluation. Jakarta: Bumi Aksara.

Aslamiah, \& Rizalie, M. (2015). The Study on Parents' Concern for the Education Process in Elementary Schools (Comparative Study at Public Elementary Schools and Private Primary Schools in Banjarbaru City. Jurnal Paradigma, 10(1), 7-15.

Baiti, N., Metroyadi, \& Wahyu. (2019). Parenting, socioeconomic, and communication between parents towards children's language skills. j-K6EM, 2(1), 1-11.

Bakar, N. A., Mamat, I., \& Ibrahim, M. (2017). Influence of Parental Education on Academic Performance of Secondary School Students in Kuala Terengganu. International Journal of Academic Research in Business and Social Sciences, 7(8), 296-304. doi:10.6007/IJARBSS/v7-i8/3230

Chen, G.-M., \& Starosta, W. J. (1996). Intercultural Communication Competence: A Synthesis. Annals of the International Communication Association, 19(1), 353-383. doi:10.1080/23808985.1996.11678935

Cologon, K., \& Mevawalla, Z. (2017). Increasing inclusion in early childhood: Key Word Sign as a communication partner intervention. International Journal of Inclusive Education, 22(8), 902-920. doi:10.1080/13603116.2017.1412515

Dalle, J., \& Mutalib, A. A. (2010). The influence of interests, facilities and family on mastery of madrasah students in solving two variable linear equations. Harati: Jurnal Sosial, Budaya, Ekonomi, dan Politik, 1(2), 43-54.

Damayanti, E. (2020). Improving children independence through Montessori teaching method. Jurnal Obsesi: Jurnal Pendidikan Anak Usia Dini, 4(1), 475-482. doi:https://doi.org/10.31004/obsesi.v4i1.333
David, A., \& Wei, L. (2008). Individual Differences in the Lexical Development of French-English Bilingual Children. International Journal of Bilingual Education and Bilingualism, 11(5), 598-618. doi:10.2167/beb478.0

Djuwitaningsih, E. W. (2018, July). Family communication pattern in women worker from Indonesia. Jurnal Penelitian Komunikasi dan Opini Publik, 22(1), 64-74.

Franzese, M., \& Iuliano, A. (2019). Correlation analysis. In S. Ranganathan, M. Gribskov, K. Nakai, \& C. Schönbach (Eds.), Reference Module in Life Sciences: Encyclopedia of Bioinformatics and Computational Biology, 1, 706-721. doi:https://doi.org/10.1016/B978-0-12-8096338.20358-0

Ganzeboom, H. B., De Graaf, P. M., \& Treiman, D. J. (1992). A standard international socio-economic index of occupational status. Social Science Research, 21(1), 1-56. doi:10.1016/0049-089x(92)90017-b

Hägglund, S., \& Samuelsson, I. P. (2009). Early childhood education and learning for sustainable development and citizenship. International Journal of Early Childhood, 49, 49-63. doi:10.1007/bf03168878

Kainuwa, A., \& Yusuf, N. (2013). Influence of Socio-Economic and Educational Background of Parents on their Children 's Education in Nigeria. International Journal of Scientific and Research Publications, 3(10), 1-8.

Kawabata, Y., Crick, N. R., \& Hamaguchi, Y. (2010). The role of culture in relational aggression: Associations with socialpsychological adjustment problems in Japanese and US school-aged children. International Journal of Behavioral Development, 1-9. doi:10.1177/0165025409339151

Kemendikbud. (2013). Communication in Parenting. Jakarta: Kemendikbud Direktorat Jenderal PAUD.

King, K., \& Fogle, L. (2006). Bilingual Parenting as Good Parenting: Parents' Perspectives on Family Language Policy for Additive Bilingualism. International Journal of Bilingual Education and Bilingualism, 9(6), 695-712. doi:10.2167/beb362.0

Lestiawati, I. M. (2013, December). The effect of parenting on social abilities of 6-7 years children. Jurnal Ilmiah Visi P2TK Paudni, 8(2), 111-119.

Maimunah, Aslamiah, \& Suriansyah, A. (2018). The Integration Of Sentra-Based Learning And Involvement Of Family Program At Early Childhood In Developing Character Building (Multi Case At Paud Mawaddah And Paud Alam Berbasis Karakter Sayang Ibu Banjarmasin, Indonesia). European Journal of Education Studies, 5(7), 49-63.

Malina, R. M. (2004). Motor Development during Infancy and Early Childhood: Overview and Suggested Directions for Research. Robert M. Malina, 2, 50-66. doi:10.5432/ijshs.2.50 
Mish, F. C. (2009). Merriam-Webster's collegiate dictionary. Springfield: MS: MerriamWebster, Inc.

Parke, R. D., Leidy, M. S., Schofield, T. J., Miller, M. A., \& Morris, K. L. (2008). Socialization. In M. M. Haith, \& J. B. Benson (Eds.), Encyclopedia of Infant and Early Childhood Development (pp. 224-235). Academic Press. doi:https://doi.org/10.1016/B978-012370877-9.001523

Polat, O., Sohtorikoğlu, Ş., Kucukoglu, E., Unsal, F. O., \& ıldız, T. (2014). THE Comparision of 54-66 months old children's readiness for primary school during preschool period and their adaptation to primary school. International Journal on New Trends in Education and Their Implications, 5(1), 169-182.

Pramling Samuelsson, I. (2011). Why we should begin early with ESD: The role of early childhood education. International Journal of Early Childhood, 43(2), 103-118. doi:10.1007/s13158-011-0034-x

Purwanti, R., Suriansyah, A., Aslamiah, \& Dalle, J. (2018). Introducing Language Aspect (English) to Early Childhood through The Combination of Picture and Picture Model, Talking Stick Model, Flashcard Media, and Movement and Song Method In B1 Group at Matahariku Bilingual Kindergarten Landasan Ulin Tengah Banjarb. European Journal of Education Studies, 5(7), 26-34.

Rakhmat, J. (1998). Communication psychology. Bandung: Remaja Rosdakarya.

Ritchie, L. D., \& Fitzpatrick, M. A. (1990). Family Communication Patterns. Communication Research, 17(4), 523-544. doi:10.1177/009365090017004007

Rizzuto, A. (2002). Speech events, language development, and the clinical situation. International Journal of Psychoanalysis, 83(6), 1325-1343. doi:10.1516/aeum-d2w6-mhkq-gw64

Romas, J. A., \& Sharma, M. (2017). Effective communication. In J. A. Romas, \& M. Sharma, Practical Stress Management: A Comprehensive Workbook (7 ed., pp. 69-89). Academic Press. doi:https://doi.org/10.1016/B978-0-12-8112953.00004-8

Runcan, P. L., Constantineanu, C., Ielics, B., \& Popa, D. (2012). The role of communication in the parent-child interaction. Procedia-Social and Behavioral Sciences, 46, 904-908. doi:10.1016/j.sbspro.2012.05.221

Salasiah, Asniwati, \& Effendi, R. (2018). Instilling character values in early childhood in the perspective of curriculum and parenting (Multi-Site Study in PAUD Islam Sabilal Muhtadin and PAUD Mawaddah, Banjarmasin, Indonesia). European Journal of Education Studies, 5 (7)., 41.

Salisch, M. v. (2001). Children's emotional development: Challenges in their relationships to parents, peers, and friends. International Journal of Behavioral Development, 25(4), 310-319.
Scarcella, R., \& Brunak, J. (1981). On speaking politely in a second language. International Journal of the Sociology of Language, 27, 59-76. doi:10.1515/ijsl.1981.27.59

Smits, J., \& Hoşgör, A. G. (2006). Effects of family background characteristics on educational participation in Turkey. International Journal of Educational Development, 26(5), 545-560. doi:10.1016/j.ijedudev.2006.02.002

Spagnola, M., \& Fiese, B. H. (2007). Family routines and rituals. Infants \& Young Children, 20(4), 284-299. doi:10.1097/01.iyc.0000290352.32170.5a

Streeck, J. (1994). Culture, meaning and interpersonal communication. In M. L. Knap, \& G. R. Miller, Handbook of Interpersonal Communication. California: Sage Publication.

Sugiharto, S. A., \& Ramadhana, M. R. (2018, December). The effect of influencer credibility on the attitude of a brand (A case study on students of Faculty of Communication and Business of Telkom University). Jurnal Ilmu Politik dan Komunikasi, 8(2).

Sugiyono. (2017). Quantitative research methods, qualitative, and $R \& D$. Bandung: PT Alfabet.

Suhaimi \& Rinawati, Y. (2018). Management of character education curriculum at Vocational High School 2 Kandangan. Advances in Social Science. Educational and Humanities Research, 272-274.

Suleman, T., \& Zairi, M. (2001). Gaining agility through supply chain management. In A. Gunasekaran, Agile Manufacturing: The 21st Century Competitive Strategy (pp. 785-807). Elsevier. doi:https://doi.org/10.1016/B978008043567-1/50039-5

Sunarto, k. (2004). Introduction to Sociology (3rd ed). Jakarta: Lembaga Penerbit Fakultas Ekonomi.

Suriansyah, A. (2014). The relationship between school culture, communication, and commitment and the state elementary school teachers' performance. Cakrawala Pendidikan, 33(3), 358-367.

Suriansyah, A., \& Aslamiah. (2015). The leadersip strategies of school, principals, teachers, parents, and the communities in building the students character. Cakrawala Pendidikan, 34(2), 234-247.

Suriansyah, A., \& Mahriati, S. (2016, July). Improving learning outcome of concept of characteristics of building space by Two Way Two Stray learning model and real mediaof Class V students of SDN Pengambangan 8 Banjarmasin City. Jurnal Paradigma, 11(2).

Topping, K., Dekhinet, R., \& Zeedyk, S. (2013). Parent-infant interaction and children's language development. International Journal of Experimental Educational Psychology, 33(4), 391-426. doi:10.1080/01443410.2012.744159

Vasilyeva, E. N., \& Shcherbakov, A. V. (2016). Parental roles and types of parentings as determinants of apreschooler's 
emotional and personal well-being. Procedia - Social and Behavioral Sciences, 233, 144 - 149. doi:10.1016/j.sbspro.2016.10.172

Wahidah, N. (2011). Communication pattern in family. Musawa, 3(2), 163-178.

Wardani, R. N., Suharsono, Y., \& Amalia, S. (2019). Relation between interpersonal communication with marriage satisfaction of carrer husband and wife. Cognicia, 7(2), 241-257.

doi:https://doi.org/10.22219/COGNICIA.Vol7.No2.241257

Wiyani, N. (2014). Nurturing early childhood character. Yogyakarta: Ar-Ruzz Media.

Wiyani, N. A. (2015). Early Childhood Character Building. Yogyakarta: Ar-ruzz Media.
Yusuf, S. (2000). Developmental psychology of children and adolescents. Bandung: Remaja Rosda Karya.

Zain, A., Saleh, M., \& Noorhapizah. (2018). Strategy for the development of religious worship and religious tolerance At Widya Dharma Paud In Banjarmasin City, Indonesia. European Journal of Alternative Education Studies, 3(2), 88106.

Zecevic, C. A., Tremblay, L., Lovsin, T., \& Michel, L. (2010). Parental influence on young children's physical activity. International Journal of Pediatrics, 1-9. doi:10.1155/2010/468526

Zhang, Q. (2007). Family communication patterns and conflict styles in chinese parent-child relationships. Communication Quarterly, 55(1), 113-128. doi:10.1080/01463370600998681 